University of Pennsylvania Carey Law School

Penn Carey Law: Legal Scholarship Repository

Faculty Scholarship at Penn Carey Law

10-29-2007

\title{
The Accidental Elegance of Aronson v. Lewis
}

David A. Skeel Jr.

University of Pennsylvania Carey Law School

Follow this and additional works at: https://scholarship.law.upenn.edu/faculty_scholarship

Part of the Business Organizations Law Commons, Legal History Commons, and the Securities Law Commons

\section{Repository Citation}

Skeel, David A. Jr., "The Accidental Elegance of Aronson v. Lewis" (2007). Faculty Scholarship at Penn Carey Law. 182.

https://scholarship.law.upenn.edu/faculty_scholarship/182

This Book Chapter is brought to you for free and open access by Penn Carey Law: Legal Scholarship Repository. It has been accepted for inclusion in Faculty Scholarship at Penn Carey Law by an authorized administrator of Penn Carey Law: Legal Scholarship Repository. For more information, please contact PennlawIR@law.upenn.edu. 


\title{
THE ACCIDENTAL ELEGANCE OF ARONSON v. LEWIS
}

\author{
David A. Skeel, Jr. ${ }^{1}$
}

\section{Introduction}

"You don’t know us,” confided the narrator in a long-running television commercial. "We don't make a lot of the products you buy. We make a lot of the products you buy better." The sponsor of the ad was a company no ordinary consumer would have ever heard of, but it was (according to the ad) a key component in cassette tapes, Sony electronics equipment and other well-known products. The company wasn't the household name, but it made the household name products better.

The Delaware Supreme Court decision in Aronson v. Lewis occupies a similar status in American corporate law. ${ }^{2}$ Unlike many key corporate law decisions, Aronson's issuance in 1984 was not heralded by stories in the Wall Street Journal and New York Times, nor in any other newspaper of note. Even now, few people other than corporate law experts are likely to recognize the name. Yet Aronson plays a pivotal role in many corporate law decisions that do get a lot more attention. When shareholders sued the board of directors of Disney, alleging that the directors had breached their fiduciary duties by approving an extravagant severance package for one-time Hollywood wunderkind Michael Ovitz, Aronson provided the framework for trial court and Supreme Court rulings that featured prominently in the press. ${ }^{3}$ More recently, allegations that many companies backdated the stock options they awarded to their executives

${ }^{1}$ S. Samuel Arsht Professor of Corporate Law, University of Pennsylvania. Thanks to Leo Strine, [others] for comments and discussion on earlier drafts, to Bill Draper for library help, and to the University of Pennsylvania Law School for generous summer funding.

2473 A.2d 805 (Del. 1984).

3 See, e.g., In re The Walt Disney Company Derivative Litigation, 825 A.2d 275 (Del. Ch. 2003). 
prompted both federal and state court litigation against the companies. As with Disney, a Delaware trial court decision was widely covered in both the general press and the business media; ${ }^{4}$ as with Disney, Aronson lay at the heart of the extensively publicized case. Indeed, Aronson may well be the single most frequently cited corporate law case of the past three decades.

Aronson established the parameters for filing derivative litigation against the directors of a corporation (or a third party, but derivative suits against third parties are now rare). A shareholder who sues derivatively alleges that the directors have breached a duty to the corporation, and seeks to pursue the litigation on the corporation's behalf. In effect, the shareholder argues that the corporation should have brought the suit itself, but because it failed to do so, the shareholder would like to step into the company's shoes. The shareholder's right to sue is based on, or “derivative” of the corporation's right- hence, the name.

The derivative mechanism would be unnecessary if companies could be expected to enforce directors' fiduciary duties themselves. But because the corporation's directors are the ones who decide whether the corporation should sue, and because most people do not make a practice of suing themselves, the cases would not be brought unless courts permitted shareholders to bypass the corporation and its board of directors. If courts let shareholders file derivative suits whenever they wished, on the other hand, corporate directors might spend their entire lives defending themselves in litigation. The first great dilemma in derivative litigation is trying to construct a framework that lets potentially meritorious suits to go forward, but discourages nuisance or strike suits which are filed simply in an effort to extract a settlement from the company.

The second dilemma arises in derivative litigation against publicly held companies. If the shareholders of these companies have relatively small stakes, they may be unwilling to pursue even meritorious litigation if they must finance it themselves. To counteract this problem, American courts have long permitted plaintiff's attorneys to take their fees from the proceeds of any recovery in the litigation. In effect, this assures that every shareholder contributes to litigation (since the recovery is reduced by the cost of the attorneys fees), rather than just the shareholders who brought the suit. While this solved one problem, it created another. Plaintiff's

${ }^{4}$ Desimone v. Barrows, C.A. No. 2210-VCS (Del. Ch. June 7, 2007). 
attorneys became the real parties in interest in many derivative cases, since they were the biggest beneficiaries if the case succeeded, and they often seemed to focus more on garnering the biggest possible fees for themselves than on the interests of the shareholders they ostensibly represented. Moreover, control of the litigation by plaintiff's attorneys increased the risk of strike suits because the attorneys, unlike a shareholder, would not be hurt if they brought litigation that harmed the company.

Aronson $v$. Lewis is nested deep within the longstanding effort to devise a framework that sensibly mediates between the competing concerns of encouraging meritorious litigation and screening out strike suits. To provide context, we will briefly survey the history of the derivative litigation, a history that shows US and UK courts adopting very different stances toward derivative litigation and the policing of corporate directors. In the UK, the principal remedy for directorial misbehavior is private action by large shareholders or intervention by regulators, and courts have repeatedly stymied shareholder litigation. US courts, by contrast, helped to facilitate shareholder litigation. After pausing to consider the rise of federal securities litigation (which is "direct" rather than derivative in nature but poses many of the same problems as derivative litigation), we focus on a controversial Delaware Supreme Court case that set the stage for Aronson. In one of the more intriguing quirks of recent corporate law history, the very same justice who had written the first decision two years earlier was also the winning lawyer in Aronson, arguing for a position that sharply limited the applicability of his earlier ruling.

\section{The Early History of the Derivative Suit}

An 1843 English case, Foss v. Harbottle, looms large in the history of Anglo-American derivative litigation. ${ }^{5}$ To be sure, derivative litigation does not really begin with Foss. Depending on the flexibility of one's definition, these lawsuits can be traced back an additional century or two, or perhaps even to Rome or the Babylonians. Even in the U.S., most notably but

${ }^{5} 2$ Hare 461, 67 Eng. Rep. 189 (Ch. 1843). The best article on the early history of American derivative litigation is a short article published fifty years ago. Bert S. Prunty, The Shareholders' Derivative Suit: Notes on Its Derivation, 32 N.Y.U. L. REV. 980 (1957). The details of the next several paragraphs are drawn in large part from this work. 
not exclusively in New York, courts had blessed lawsuits that we would now call derivative before 1843. But for two reasons, Foss is a convenient starting point. First, courts on both sides of the Atlantic treated the case as a watershed throughout the nineteenth century. Second, the divergent paths of doctrinal development after Foss in the U.S. and U.K. provide a revealing perspective on alternative strategies for policing corporate managers.

In Foss, a group of shareholders of a nonprofit corporation sought to sue its managers, alleging that the managers had misused their power. Although the court recognized the right of shareholders to sue under some circumstances, it concluded that these particular shareholders were not entitled to proceed because their allegations related to concerns that affected all of the company's shareholders, and the shareholders as a group had not taken formal action. A shareholder plaintiff, the court held, can only sue if the action in question could not have been approved by the shareholders as a group, or if the managers had engaged in fraudulent misrepresentation. (As an alert reader will have noticed, Foss's reputation as the wellspring of derivative litigation is mildly ironic, given that the case says more about the restrictions on derivative litigation than about the legitimacy of this device.)

In England, subsequent nineteenth century cases very clearly bore the imprint of Foss, hewing closely to both its letter and its spirit. An 1867 case construed Foss's reference to managerial fraud to authorize minority shareholders to sue a majority block that had defrauded them. ${ }^{6}$ In a case decided eight years later, the court treated majority/minority fraud and the fraud exception as one and the same. Under Foss, the court said, shareholders can only sue if: 1) the actions in question are ultra vires; or 2) the wrong has been committed by a majority group against the minority. English courts have continued to limit shareholders' right to sue in this fashion ever since. Although several legislative adjustments have been made in recent years in an effort to widen the scope of derivative legislation, they have had very little impact on the frequency of derivative litigation. Derivative litigation has always been extremely uncommon in England, and it remains so today. ${ }^{7}$

${ }^{6}$ Atwool v. Merryweather, L.R. 5 Eq. 464 [check].

7 These developments and the paucity of UK derivative litigation are chronicled in John Armour, Enforcement Strategies in UK Company Law: A Roadmap and Empirical Assessment (unpublished manuscript, 2007). 
Although American derivative litigation seems to have developed from the same roots, a very different tree, with vastly more foliage, emerged in this country in the course of the nineteenth century. Unlike their English brethren, American courts never limited shareholder litigation to cases involving ultra vires acts or fraud by a controlling majority. Several of the early cases were not even aimed at managerial misbehavior; shareholders' real target was a third party. In the best known of the suits, Dodge v. Woolsey, ${ }^{8}$ a shareholder wanted to challenge a state statute that imposed an income tax on the corporation. Because the company's directors were unwilling to pursue the litigation, the Supreme Court agreed that the shareholder could take up the cudgel himself.

While US courts were far more permissive than their British counterparts, shareholders' right to sue derivatively was never absolute. The courts recognized that simply letting any shareholder sue whenever the directors were not willing to do their bidding would wreck havoc on corporate governance. Early on, they began to impose procedural restrictions. Most importantly, shareholders were required to make demand on the directors before suing- that is, a shareholder could not head to the courthouse until she had first asked directors to take actions themselves. "I think it is necessary to show, in order to warrant the interference of individual stockholders," a New York judge said in an early case, that the constituted representatives of the company, whose especial duty it is to vindicate its rights, have been requested to institute proceedings for that purpose, and have refused to do so." ${ }^{9}$ Even with these restrictions, however, shareholders had far more ability to bring a derivative action in the United States than did their counterparts in England.

Not only did US courts define derivative standing quite broadly, but they subsequently encouraged derivative litigation in another way: by giving attorneys an incentive to participate. In ordinary American litigation, each party bears the costs of its own attorneys. While this rule

${ }^{8} 59$ U.S. (How.) 331 (1856).

${ }^{9}$ House v. Cooper, 30 Barb. 157, 158 (N.Y. 1858). U.S. Supreme Court recognition of the demand requirement is often traced to Hawes v. City of Oakland, 104 U.S. 450 (1881) [check]]. Some states also required that demand be made on the other shareholders, and precluded suit unless a majority of the shareholders approved. The shareholder demand lost much of its bite over time, however, because courts carved out numerous exceptions. Shareholder demand is generally waived, for instance, if the corporation has numerous shareholders and making demand would therefore be costly or inconvenient. 
works tolerably well under most circumstances, it discourages the shareholders of widely held corporations from pursuing derivative litigation, even if the managers of their company have acted very badly. If a shareholder holds only a few shares, the costs of pursuing the litigation will almost always dwarf her pro rata share of the expected recovery from the lawsuit. And even if she has a large enough stake to justify taking the laboring oar, she may hesitate to do so, in the hope that someone else will, and will bear the costs, instead. American courts vitiated this problem by applying the "common fund" exception to the usual rule that the plaintiff who brings a suit is saddled with its costs. Under the common fund doctrine, the proceeds of a recovery with numerous beneficiaries is first used to pay attorneys fees and other costs, before anyone else gets a recovery. In effect, paying the lawyers first forces all of the shareholder to bear the cost, since they (or the corporation) recover only after-attorney dollars.

English judges never went in for any of this. Just as they held the line on derivative standing, they never fudged the rules on attorneys fees to make it easier for shareholders to bring derivative litigation. In England, the ordinary rule for attorneys fees is that the loser in a lawsuit pays the lawyers for both sides. England's "loser pays” rule is a particularly unattractive prospect for derivative suit plaintiffs. If the suit fails, as many lawsuits do, the shareholder plaintiff is responsible for not just one, but two sets of attorneys fees. Even shareholders who are not afraid of risk will think twice about making that kind of wager.

Why were US courts so much more accommodating to the derivative mechanism than their British counterparts? The contrast can perhaps be traced, in part, to differences in corporate evolution in the two countries. As first documented in a famous study by Adolph Berle and Gardiner Means, ${ }^{10}$ the shareholdings of many of America’s large corporations were widely dispersed by the beginning of the twentieth century. Shareholders' small stakes and distance from the daily operations of the company made it difficult for them to monitor the company's managers. The expansion of derivative litigation, together with the payment of attorneys fees if the litigation was successful, gave shareholders a tool for policing their managers. "Equity came to the relief of the shareholder," as the Supreme Court put it in 1949, and "allowed him to step

\footnotetext{
10 ADOLPH BERLE \& GARDINER MEANS, THE MODERN CORPORATION AND PRIVATE PROPERTY (1932).
} 
into the corporation's shoes and to seek in its right the restitution [against managers who profit personally at the expense of their trust] he could not demand in his own." 11

In contrast to the US, family control was the norm even with the largest UK corporations until much later. ${ }^{12}$ Because shareholders were more actively involved in the company’s affairs and could use ordinary internal governance mechanisms such as corporate voting to police its managers, they had less need for a robust external enforcement mechanism like derivative litigation. UK shareholdings did eventually disperse after World War II, but they were still more concentrated than in the US, due in part to tax and dividend policies that encouraged institutions rather than individuals to hold stock. ${ }^{13}$

Differences in corporate ownership do not seem to entirely explain the divergence between the US and UK, however, because the expansion of derivative standing in the US began well before widely scattered shareholdings became a characteristic feature of large US corporations in the early twentieth century. An additional factor may have been the dilemma that gave rise to Dodge v. Woolsey and other derivative suits against third parties. The directors' failure to sue in Dodge does not seem to have reflected disagreement about the validity of the state income tax in question. The directors worried (one suspects), instead, that it would be a fool's errand for the corporation itself to seek relief in the courts of the state that had imposed the tax. But if the suit were brought by shareholders who lived in another state, the calculus immediately changed, for one simple reason: unlike the corporation itself, out-of-state shareholders could invoke diversity jurisdiction and challenge the statute in federal court. From this perspective, a generous interpretation of derivative standing facilitated challenges to potentially unconstitutional legislation that might not have been possible otherwise. No doubt other factors came into play as well. In short, the divergent evolution of the derivative mechanism in the US and UK seems to have reflected the response of common law courts to the peculiar dynamics of the corporate landscape in each country.

${ }^{11}$ Cohen v. Beneficial Industrial Loan Corp., 337 U.S. 541, 548 (1949).

12 See, e.g., Brian R. Cheffins, History and the Global Corporate Governance Revolution: The UK Perspective, 43 BUS. HIST. 103 (2001)(UK ownership did not become diffuse until after World War II).

13 This view is outlined in Armour, supra note 7. 
By the 1940s, American derivative litigation had acquired the unsavory reputation that has dogged it ever since. Business leaders harnessed this dissatisfaction by commissioning a study of derivative litigation in New York. Overseen by Franklin Wood for the Chamber of Commerce of the State of New York, the study became known, appropriately enough, as the Wood Report. "Although derivative actions have been hailed in some quarters as a wholesome corrective,” Wood wrote, “their increase has been accompanied by a considerable body of literature commending improvements and substitutes for such actions, which suggests that ... the remedy has become maladjusted to the disease. It is hardly possible, certainly, to attribute the increase of such litigation to a decline in business morals since the days of [notorious robber barons] Jim Fisk and Jay Gould.”14

Wood and his peers examined 1,266 lawsuits brought by shareholders in two New York counties and the U.S. District Court for the Southern District of New York over the ten year period from 1932 to 1942. More than half of the cases (693) involved closely held corporations, but Wood directed most of his attention to the 573 publicly held company cases. The pecuniary recoveries in these cases amounted to only $5 \%$ of the amounts alleged in the $2 \%$ of cases that were successfully tried, and another $3 \%$ in the $6 \%$ of cases that produced court approved settlements. The paucity of recoveries, Wood concluded, with the sarcastic tone that makes his report entertaining reading more than sixty years later, "is a record of sorts."15 The report criticizes the frequency with which the suits were brought by shareholders with little stake in the company, complaining that "the smallest of small investors have suddenly become masters of the most intricate details of corporate finance, and the most alert of sentinels to employ attorneys and attack corporate management on the slightest suspicion of a big lawsuit." ${ }^{16}$ The potential benefits to the plaintiffs' of success in a recent case, he noted, were $\$ 3.57, \$ .41, \$ 2.51$, $\$ .17$ and

14 CHAMBER OF COMMERCE OF NEW YORK STATE, SURVEY AND REPORT REGARDING STOCKHOLDERS' DERIVATIVE SUITS 96 (1944)(cited hereafter as WOOD REPORT).

${ }^{15}$ Id. at 7. Wood did acknowledge that private settlements in other cases undoubtedly increased the overall shareholder recoveries.

16 "Women," he notes, "are prominent among these one-suit students of law and finance." Id. at 46. 
$\$ .65 .^{17}$ In reality, Wood concluded, the plaintiffs had very little to do with the litigation at all. They were essentially a front for the plaintiff's attorneys, who were the real beneficiaries of the derivative suits because their fees were paid in full if the litigation provided a benefit to the company. The attorneys' "shoddy burlesque of a professional relationship to the clients," as Wood put it, "makes the ambulance-chaser by comparison a paragon of propriety. He at least represents a real client, with usually real injuries, and a legitimate interest in $50 \%$ of the recovery." 18 The attorneys' fees were "among the largest possible for practitioners in any field of law," and the corporation usually indemnified the directors' fees as well, which meant it essential bore the costs of both sides.

It should be noted that Wood had no quarrel with derivative litigation in the close corporation context, as this litigation was usually brought by minority shareholders with a significant stake who alleged misbehavior by the majority. For publicly held firms, on the other hand, derivative litigation needed radical surgery. Indeed, Wood's report was in the nature of a brief (a brief commissioned by the Chamber of Commerce, a leading business group). The solution, he concluded, was to limit standing to shareholders who owned stock at the time of the alleged wrongdoing, and to require the shareholder plaintiff to post security for costs in the event the litigation were found to have been meritless.

With an alacrity that reflected the influence of business, the seriousness of the flaws in the derivative mechanism, the persuasiveness of Wood's handiwork, or some combination of the three, the New York legislature enacted the nation's first security for expenses statute the same month report was issued. Under the New York provision, a plaintiff was required to post "security for reasonable expenses, including attorneys fees," unless the plaintiff owned at least $5 \%$ or $\$ 50,000$ worth of the company’s stock." ${ }^{\prime 19}$ For those who viewed derivative litigation as an essential tool for monitoring the managers of large corporations, the new provision was a worrisome development. In an article published within months of the Wood Report, a leading scholar of shareholder litigation lambasted the Wood report and predicted that the reforms it

\footnotetext{
${ }^{17}$ Id. at 49 .

${ }^{18}$ Id. at 47.

${ }^{19}$ Ch. 668, sec. 61-b [1944] N.Y. Laws 1455 (later amended by NY BUS. CORP. Law sec. 67.
} 
inspired meant “the death knell of stockholders' derivative suits in New York.” ${ }^{20}$ Few shareholders held 5\% of the stock of the nation's largest corporations, the article pointed out, and only the wealthy ("who presumably can be persuaded not 'to upset the apple cart'”) will hold $\$ 50,000$ worth of stock. Given the cost of posting bond, and the inevitable riskiness of these suits, the article concluded, few shareholders will be willing to sue. "Since all means of control other than the stockholder's suit are expressly rejected by the Report ..., the practical abolition of stockholders' suits constitutes an invitation to corporate management to repeat the scandalous behavior exposed during the past ten years on governmental investigations and in 46 successful civil suits in the three courts studied” by the Wood report.

Although derivative litigation may indeed have been chilled for a time, the prophesies of its demise were greatly exaggerated. Twenty years later another commentator reported, based on anecdotal evidence and a quick survey of the West's Decennial Digest, that the number of derivative suits had grown dramatically from 1956-1966, as compared to the previous decade. ${ }^{21}$ Courts and legislatures had lowered the barriers to derivative litigation in a variety of ways. To ease the bite of the security for expenses statutes, for instance, they let shareholders band together to clear the $\$ 50,000$ threshold. Courts also held that these state procedural strictures did not apply to litigation brought under the federal securities acts. The freedom from state procedural impediments enjoyed by litigation based on the securities acts was one of several developments that would make securities litigation especially attractive for aggrieved investors, as we shall see in a moment. For now, the principal point is simply that by the mid 1960s, derivative litigation was once again alive and well.

\section{Securities Class Actions and the Expanding Scope of Securities Law}

Derivative litigation has never been the only option for suing corporate directors who have allegedly violated their fiduciary duties. If a shareholder has been personally harmed by the

20 George D. Hornstein, The Death Knell of Stockholders' Derivative Suits in New York, 32 CALIF. L. REV. 123 (1944). The quotes in the text below are at p.143 and p.144 respectively.

21 Daniel J. Dykstra, The Revival of the Derivative Suit, 116 U. PA. L. REV. 75 (1967). 
directors’ misbehavior, she can sue directly rather than bringing a derivative action on behalf of the firm. By suing directly, a plaintiff (and her attorney, of course) sidesteps all of the nettlesome prerequisites that complicate derivative litigation: no need to worry about demand on the directors, security for expenses, or any of the other special obstacles to derivative litigation. If the plaintiff wins, moreover, any recovery comes straight to her rather than going first (and sometimes only) to the corporation.

From the plaintiff's perspective, suing directly thus is a dream by comparison to the derivative mechanism. But it has two obvious limitations. The first is that the plaintiff must persuade the court that the injury is indeed direct. The line between direct and derivative in the caselaw is fuzzy, to put it charitably, but courts tend to treat allegations of general mismanagement as derivative (the initial victim of the harm is the company itself; shareholders are harmed only indirectly, since the deterioration in value lowers the value of their shares), while interference with the incidents of a share of stock, such as its voting rights, is characterized as a direct harm. Second, the small stakes of most shareholders in a large corporation make solo litigation unattractive both for them and for an attorney.

The advent of large scale securities litigation in the 1960s addressed both of these concerns, dramatically reshaping the landscape of shareholder litigation. The securities acts of 1933 and 1934 had introduced a handful of causes of action for investors who are harmed in connection with the purchase, sale, or voting of securities. ${ }^{22}$ These causes of action are direct, but the provisions that explicitly invited investors to sue were confined to relatively limited events such as the purchase of stock in connection with an initial public offering. They also were subject to restrictions quite similar to the derivative suit prerequisites, such as a security for expenses provision (as well as a short statute of limitations).

The dramatic expansion of federal securities litigation would come not from any of these provisions, however, but from two broad antifraud provisions in the 1934 act, section 10(b) and section 14(a), neither of which explicitly authorized private shareholder litigation. Shareholder plaintiffs and their lawyers argued that they had an implied right to sue under the two antifraud provisions. " $[\mathrm{I}] \mathrm{t}$ is likely that the Congressmen involved [in the enactment of the securities acts]

\footnotetext{
22 These provisions are listed and described in LOSS, SELIGMAN, AND PARADES ON SECURITIES REGULATION [add cite].
} 
would ... have been amazed if told that the acts which they were passing would have the effect of granting an implied private right of action,” the leading academic critic of these suits groused. ${ }^{23}$ But courts increasingly allowed the suits to go forward, and the Supreme Court gave its imprimatur in $1964 .{ }^{24}$ To makes matters even better, at least from the defendants' perspective, courts held that these suits were not subject either to the procedural restrictions that applied to the other, explicitly authorized causes, or, as we have seen, to the state law restrictions imposed on derivative litigation. ${ }^{25}$

The SEC fueled the growth of federal securities litigation by steadily expanding the scope of the 1934 Act in general, and Rules 14 and 10b-5 in particular. Although the proxy rules apply only to publicly held companies, the SEC defined publicly held to include not only companies listed on the national exchanges, but any company with at least $\$ 1$ million in assets and 500 shareholders. ${ }^{26}$ Of even greater moment, the Commission, under its activist Chairman William Cary, interpreted Rule 10b-5 to prohibit inside trading both by insiders and wide range of others, and it used the rule to police any misdisclosure made by the company. In one of its most important rulings, the SEC marveled at its own handiwork, praising the "wholly new and farreaching body of federal corporation law," and quoted from a recent case that had described Rule $10 \mathrm{~b}-5$ as "a potent weapon for enforcement of many fiduciary duties. ${ }^{27}$

The last piece in the puzzle was the class action device. If the litigation was framed as a class action representing many or all of a company's shareholders, rather than solo litigation, it

${ }^{23}$ David S. Ruder, Civil Liability Under Rule 10b-5: Judicial Revision of Legislative Intent?, 57 NW. U.L. REV. 627, 654 (1963).

${ }^{24}$ J.I. Case Co. v. Borak, 377 U.S. 426 (1964).

${ }^{25}$ Here, too, David Ruder sounded a dissenting note. It is "not unreasonable to suggest," he wrote, "that Congress might be interested in providing limitations on liability similar to those contained in the 1933 and 1934 acts.” David S. Ruder, Pitfalls in the Development of a Federal Law of Corporations by Implication Through Rule 10b-5, 59 NW. U.L. REV. 185, 207 (1964).

2615 U.S.C. sec. 77l(g)(added by 1964 amendments to the 1934 act). The dollar amount has been adjusted in recent years to account for inflation, and is currently $\$ 10$ million. 17 C.F.R. sec. 240.12g-1.

${ }^{27}$ In the Matter of Cady, Roberts \& Co., CCH FED. SEC. L. REP. Para 76803, at 81016 (1961)(quoting McClure v. Borne Chemical Co., Inc., 292 F.2d 824, 834 (3d Cir. 1961). 
would be worthwhile for attorneys to pursue even if any given shareholder's stake was small. In the 1960s, the usefulness of the class action strategy was greatly enhanced by the redrafting of Federal Rule of Civil Procedure 23. ${ }^{28}$ Although originally intended to strengthen enforcement of the civil rights laws, new Rule 23 quickly became an important feature of securities litigation, as well as direct shareholder litigation under state law. ${ }^{29}$ Securities class actions had all of the benefits of a derivative suit, but none of the pesky limitations. They quickly became the avenue of choice for many lawsuits that might previously have been brought as state law derivative suits.

In the 1970s, the pendulum shifted back, as the Supreme Court began to narrow the scope of securities litigation. Of particular importance for our purposes, the Court held that Rule 10b-5 could not be used to police violations by directors or officers of their fiduciary duties. ${ }^{30}$ Fiduciary duty was the province of state corporate law, according to the Court, and Congress didn't intend to subsume it into the antifraud provisions of the securities laws. In other cases, the Court limited relief to investors who had actually bought or sold securities (denying relief to those who claimed they were tricked into holding their stock rather than selling by the defendants' misstatements) and held that Rule 10b-5 required a showing of scienter- it wasn't enough to show that the defendant had acted negligently. ${ }^{31}$

Both federal securities class actions and state law derivative suits have continued to be controversial. In the decades after the Wood Report, researchers conducted several subsequent

28 These changes also added Federal Rule 23.1, which requires the plaintiff in a derivative suit to describe "efforts, if any, made by the plaintiff to obtain the action the plaintiffs desires from the directors ... and the reasons for the plaintiff's failure to obtain the action or for not making the effort." The rule thus incorporates the demand requirement for derivative cases brought in federal court, while leaving the content of the requirement to state law.

29 The most prominent source of state law corporate class actions is litigation over an acquisition or sale. These suits are direct because the price obtained for shareholders is not a corporate cause of action. A recent study of litigation in Delaware found that nearly $79 \%$ of the fiduciary duty actions filed in Delaware were class actions, and nearly all of these arise in the acquisition context. Robert B. Thompson \& Randall S. Thomas, The Public and Private Faces of Derivative Lawsuits, 57 VAND. L. REV. 1747, 1762 \& Tbl 2 (2004).

30 Sante Fe Industries, Inc. v. Green, 430 U.S. 462 (1977).

31 Blue Chip Stamps v. Manor Drug Stores, 421 U.S. 723 (1975)(purchase-sale requirement); Ernst \& Ernst v. Hochfelder, 425 U.S. 185 (1976)(scienter). 
studies of shareholder litigation. In the best known and most influential of these studies, Roberta Romano studied ever shareholder suits brought against publicly held firm from the late 1960s

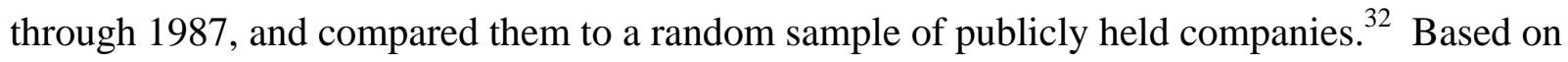
her findings that large majorities of the cases settle and that the per share recoveries in the settlements are generally small, Romano states that the "data support the conclusion that shareholder litigation is a weak, if not ineffective, instrument of corporate governance.”33 Defenders of shareholder litigation argue, among other things, that many of the settlements in the cases actually are quite large in absolute terms; and that the threat of suit may deter managerial misbehavior even if the litigation does not produce substantial benefits for the particular corporation involved. For present purposes, we should note (while sidestepping the debate over efficacy) that Romano's study, like much discussion of shareholder litigation, lumps federal securities class actions and state derivative suits together. While I too have emphasized some of the commonalities, there may be good reasons for viewing them differently in the end, as we shall see.

\section{Zapata v. Maldonado}

If the general background to Delaware's decision in Aronson v. Lewis was the never ending debate whether shareholder litigation is a valuable tool for policing managers or simply a get rich quick scheme for plaintiffs' attorneys, the immediate background was a case called Zapata Corp v. Maldonado. ${ }^{34}$ Zapata was the Delaware Supreme Court's much-awaited response to a clever new strategy by corporate directors to take control of (and thus to kill) derivative litigation that previously would have proceeded without interference.

Zapata itself nicely illustrates the strategy. Zapata arose after the directors of Zapata Corporation moved back the exercise date of their stock option plan, so that they could exercise

32 Roberta Romano, The Shareholder Suit: Litigation without Foundation?, 7 J.L. ECON. \& ORG. 55 (1991).

33 Id. at 84.

34430 A.2d 779 (Del. 1981). 
the options before they announced the company's intention to make a tender offer for its own shares at a hefty premium over the current price. If they bought the stock while the stock price was still low, the directors would have a much lower tax bill on their gains (the difference between the lower stock price, rather than the higher one, and their exercise price), while the company would have a correspondingly lower deduction for the expense to it of the compensation. Pushing back the exercise date benefited the directors themselves, in other words, but hurt the company. Shareholders brought a derivative suit against the Zapata directors alleging that the options slight-of-hand violated their duty of loyalty.

In the past, directors who had been caught with their hands in the cookie jar like this could not have done anything to slow or stymy the litigation's onward march. They all had participated in the decision to move back the exercise date, so demand clearly would be excused. But Zapata's directors had one last trick up their sleeves. Four years after the litigation was initially filed, the directors appointed two new directors to vacancies created by the resignations of several of their peers. The board then created an "Independent Investigation Committee" consisting solely of the two new directors. This committee would determine whether the litigation should continue.

In a much discussed New York decision, the court had given considerable deference to a similarly constituted special litigation committee. ${ }^{35}$ Under the New York approach, the court would assess the independence of the directors on the committee and the thoroughness of their investigation. But the committee's substantive decision on the litigation would enjoy the same business judgment rule deference as other directorial decisions.

The New York approach spurred cries of alarm from advocates of derivative litigation. The “independent” committees set up by directors who had been sued invariably concluded that the litigation would simply be too costly, or the prospects of recovery too slim, to justify continuation. Some observers attributed the defendant-colored glasses with which the committees seemed to view litigation to a "structural bias" in board decision making: many board members were beholden to or had longstanding relationships with, the company’s chief executive, and board members tended to come from the same professional and social circles. Given this bias, they argued, courts should give little deference to the committee's conclusions.

35 Auerbach v. Bennett, 393 N.E.2d 994 (N.Y. 1979). 
"[T]o follow ... the path suggested by the cases to date," one commentator warned, "will certainly mean the virtual death of the derivative suit.",36 If the litigation implicates a majority of the directors, he concluded, the board should never be permitted to dismiss it. ${ }^{37}$

In Zapata, Justice William Quillen announced that Delaware would neither defer to the decisions of special committees nor ignore their recommendation. "If, on the one hand, corporations can consistently wrest bona fide derivative actions away from well-meaning derivative plaintiffs through the use of the committee mechanism," he wrote, "the derivative suit will lose much, if not all, of its generally recognized effectiveness as an intra-corporate means of policing corporate directors. If, on the other hand, corporations are unable to rid themselves of meritless or harmful litigation and strike suits, the derivative action, created to benefit the corporation, will produce the opposite, unintended result. ${ }^{38}$

To strike this balance, Zapata established a two part test for reviewing a committee recommendation to terminate the litigation. The court should first assess the independence, good faith, and reasonable investigation of the committee, as under the New York approach. But this would not end the inquiry due, at least in part, to the concerns about psychological bias. Because the "question naturally arises whether a 'there but for the grace of God go I' empathy might play a role" when "directors are passing judgement on fellow directors in the same corporation," Quillen wrote, the analysis should proceed to a second step: "The Court should determine, applying its own independent business judgment, whether the motion should be granted."

This is a radically different standard than the New York approach. The second step speaks in terms of business judgment, but it is the court's own business judgment, not the judgment of corporate businessmen or businesswomen, that determines the litigation's fate. In

${ }^{36}$ George W. Dent, Jr., The Power of Directors to Terminate Shareholder Litigation: The Death of the Derivative Suit?, 75 NW. U.L. REV. 96, 146 (1980).

${ }^{37}$ Id. at 122, 141-42. In an initial draft of its Principles of Corporate Governance, the American Law Institute's reporters adopted a similar position, holding that a special litigation committee can only be appointed by disinterested directors, and at least one court followed their lead. See Miller v. Register \& Tribune Syndicate, Inc., 336 N.W.2d 709 (Iowa 1983). The reporters later eliminated the blanket prohibition. These developments are discussed in Dennis J. Block \& H. Adam Prussin, Termination of Derivative Suits Against Directors on Business Judgment Grounds: From Zapata to Aronson, 39 BUS. L. 1503, 1518-21 (1984).

${ }^{38}$ Zapata Corp. v. Maldonado, 430 A.2d 779 (Del. 1981)(citations omitted). 
effect, Zapata ripped the decision out of the committee's hands. It also had put the chancery court in the position of deciding whether a corporation should pursue derivative litigation. But it only had these effects in cases where demand would otherwise have been excused. Zapata itself had nothing to say about the demand futility requirement. This was understandable enough given the circumstances of Zapata itself. If ever there were a case where demand would be excused, Zapata was it. But the line between demand excused and demand required cases was quite murky in Delaware law, as elsewhere. In Delaware, this distinction had suddenly become extraordinarily important, thanks to the second step of the Zapata test.

It was into this breach that Aronson sailed.

\section{The Chancery Court Decision}

The complaint in Aronson tells a simple tale of behavior that could be viewed as either blandly unobjectionable or patently nefarious, depending on one's point of view and the facts lying behind the plaintiff's five page opening salvo. The plaintiff was a shareholder of Meyers Parking System, Inc., a nationwide network of parking lot facilities that had been spun off from Prudential Building Maintenance Corporation in 1979. Leo Fink, who owned 47\% of Meyers' stock and had retired from Prudential in April, 1980, had contracts with both corporations. He had signed a consulting contract with Prudential, 25\% of which would be billed to Meyers, and an employment contract with Meyers. The Meyers contract entitled Fink to \$150,000 per year, plus a bonus of $5 \%$ of every dollar of Meyers's pretax profits over $\$ 2,400,000$. If either side terminated the agreement, Fink would be employed as a consultant at $\$ 150,000$ per year for the first three years, $\$ 125,000$ for the next three, and $\$ 100,000$ thereafter, whether or not Fink, who was 75 when the agreement began on January 1, 1981, was able to perform any services. He also had received $\$ 225,000$ in interest free loans. These arrangements, according to the complaint, "were improper, unnecessary, a waste of corporate assets and made for no valid business purpose."39

${ }^{39}$ Complaint, p.3. 
The plaintiff sued without first asking the Meyers directors to take action themselvesthat is, without making demand. This was not an oversight, of course. The plaintiff insisted that demand should be excused in this case. His explanation, as set forth in paragraph 13 of the complaint, was as follows:

Demand has not been made upon the directors of Meyers to bring this action because such attempt would be futile for the following reasons:

(a) All of the directors in office are named as defendants herein and they have participated in, expressly approved and/or acquiesced in, and are personally liable for, the wrongs complained of herein.

(b) Defendant Fink, having selected each director, controls and dominates every member of the Board and every officer of Meyers.

(c) Institution of this action by present directors would require the defendant directors to sue themselves, thereby placing the conduct of this action in hostile hands and preventing its effective prosecution. ${ }^{40}$

In response, the defendants asked the chancery court to dismiss the complaint for failure to make demand. In their briefing in the chancery court, the defendants repeatedly emphasized two points: first, the allegations really implicated Fink, not the board as a whole; and second, the attempt to implicate the rest of the board "has relied on conclusory and self-manufactured claims of 'futility' in order to avoid the salutory requirements of Rule 23.1,” which requires that a derivative suit plaintiff either make demand or state with particularity the reasons for not making demand. ${ }^{41}$ " $[\mathrm{T}]$ he only fact alleged in support of the allegation of control and domination of Meyers’ Board by Mr. Fink,” the defendants argued, was “the selection of each member by Mr. Fink.”

40 Complaint, Para. 13, p.4.

41 Defendants' Memorandum of Law in Support of Their Motion to Dismiss Plaintiff's Complaint, p.9 (Oct. 7, 1982). The quote in the text below appears on p.12. 
In his reply memo, the plaintiff reiterated the strong circumstantial links between Fink and the other nine members of Meyers' board. 'Fink, through his 47\% ownership of Meyers' outstanding stock," plaintiff argued, “dominated and controls each director and officer of Meyers, having selected each such officer and director." ${ }^{\prime 2}$ Not only is $47 \%$ of the stock enough to give effective control of a publicly held company, but Fink, together with the four other directors who also were directors of Meyers, owned 57.5\% of the outstanding stock. Plaintiff's response also raised further questions about the legitimacy of Fink's contract with Meyers, stating that "Fink performs little or no services for Meyers and because of his advanced age, cannot be expected to perform any services."

By the end of the briefing and oral argument, the key issue seemed clear: what kind of allegations suffice to show that a board of directors is too tainted to make an objective decision whether to pursue a cause of action, so that demand on the board is excused? As with the parties' briefs, it was this issue that occupied much of Vice Chancellor Hartnett's opinion. The Vice Chancellor rejected the links the plaintiff had sought to establish between Fink and the board as a whole. Fink's 47\% stock ownership was not by itself sufficient to call into question the impartiality of the board of directors, and plaintiff's allegation that he dominated and controlled the other directors was "merely conclusory and [did] not allege control with particularity” because it was not supported by any "cogent facts." ${ }^{43}$ The allegation that Fink was in league with the other officer directors was similarly unavailing because there were "no allegations in the complaint which show that these four directors [were] aligned with Fink.”

At this point, the opinion took a surprising turn. After concluding that the plaintiff did not adequately allege that the board itself was tainted, the vice chancellor said that a court "often must look for evidence of why approval would have been wrongful," and conducted his own inquiry into the underlying contract. ${ }^{44}$ In his view, the provision in Fink's compensation agreement which guaranteed payment even if Fink was unable to perform any services "may

42 Plaintiff's Answering Brief in Opposition to Defendants' Motion to Dismiss the Complaint, p.2 (Oct 26, 1981). The quote in the text below appears at p.4.

${ }^{43}$ Lewis v. Aronson, 466 A.2d 375, 382 (Del. Ch.1983). The quote that follows appears on the same page.

${ }^{44}$ Id. at 383. 
have constituted the approval of a transaction wasteful on its face. ${ }^{45}$ Because this provision may have been "one which no reasonable man could have approved in the belief that the corporation was getting a quid pro quo," the court concluded, demand was excused and the defendants' motion to dismiss must be denied.

In a short addendum attached to the opinion after the defendants asked for the reargument, the vice chancellor suggested that his decision to take his own look at the underlying transaction, rather than just the plaintiff's allegations about the directors' complicity, was inspired at least in part by Zapata. In order to properly balance shareholders interest in bringing corporate causes of action with the directors' right to "“rid [the corporation] of detrimental litigation,”” as Zapata instructs, "[e]ach case in which there has been no demand must ... be carefully scrutinized and analyzed according to its own unique set of facts, taking into account the totality of the circumstances and the competing interests." ${ }^{46}$

Before we follow the parties to the Delaware Supreme Court, it is worth mentioning that the Aronson case itself seems to have exhibited only one of qualities that make shareholder litigation controversial. Harry Lewis, the plaintiff, whose only evident involvement in the litigation was his serving as the named plaintiff, cropped up in so many cases in the 1970s and early 1980s that he was rumored to be simply a "street name" used by plaintiffs" lawyers. He did exist, however, and by one count his name appeared in 81 judicial opinions in securities cases and derivative litigation. ${ }^{47}$

\section{Defining Demand Futility: The Supreme Court Decision}

\section{Id. at 384.}

${ }^{46}$ Id. at 385 (quoting a case another case that he had recently decided, Bergstein v. Texas Intern. Co., 453 A.2d 467 (Del Ch. 1982), which in turn quotes and discusses Zapata).

47 DEBORAH DEMOTT, SHAREHOLDER DERIVATIVE ACTIONS: LAW AND PRACTICE para. 1:5 n.1 (2003)(describing the mystery surrounding Harry Lewis). Allegations that leading shareholder litigation firm Milberg Weiss paid "professional plaintiffs" to serve as the nominal plaintiffs in its suits led to indictments in 2006 and contributed to the loss by the firm of its once dominant role in federal securities litigation. See, e.g., Nathan Koppel, Milberg's Case for Kickbacks, WALL ST. J., Aug. 4-5, 2007, at A3 (discussing debate whether such fees are problematic). 
The argument in the Supreme Court was curious in one respect, and as we shall see later, dramatic in another. It was curious in that the unusual trajectory of the chancery court opinion put the parties in an odd posture before the Supreme Court. "The defendants say that they agree with much of the Opinion below," as the plaintiff (and appellee in the Supreme Court) put it, "but disagree with the result ... For his part, the plaintiff finds himself in disagreement with much of the opinion below, but, at the same time, agrees with the result."48 The defendants praised the vice chancellor's conclusion that Fink’s 47\% stock ownership did not constitute a factual basis for suggesting that he dominated and controlled the board of directors. Even if Fink had owned an absolute majority and could single handedly select the directors, they argued, this would not show that the directors failed to exercise independent judgment. There was simply no adequate factual allegation that the directors could not be trusted to make an appropriate decision whether to pursue the litigation. They also agreed that acquiescence in or approval by the directors of the challenged transactions is not a basis for excusing demand. It was only in the opinion's final twist, with the court's conclusion that it could infer the possibility of waste from a provision in the contract, the defendants argued, that the lower court lost its way.

The plaintiff, despite having won below, spend much of his brief insisting, contrary to the vice chancellor's conclusion, that Fink's 47\% stock ownership clearly enabled him to dominate and control the rest of the board. Having shown that the defendant had a controlling block of stock, the plaintiff argued, he should not be required to show actual domination- that is, that the directors selected by the defendant failed to exercise independent judgment- until after he had an opportunity for full discovery. "To force the plaintiff to plead more facts" at the outset of the case, before having the opportunity for discovery, he complained, "which is the inevitable consequence of the Vice Chancellor's ruling on the control issue, represents judicial insistence on the necessity to plead voluminous evidence contrary to the letter and spirit of the Rules of the Court of Chancery."49

48 Plaintiff Below-Appellee's Answering Brief, Aronson v. Lewis, No. 203 (Del. S.Ct. Oct. 5, 1983), at 9.

49 Id. at 16. 
Both concluded with dire predictions of the effect on future derivative litigation if their view were rejected. "Contrary to Zapata," the defendants warned, "the decision below minimizes a board's ability to manage by redefining self-interest in such an expansive manner that demand on the board will almost always be excused." ${ }^{50}$ Under the vice chancellor's conclusion that a board's independence could be called into question if a transaction appears to have been wasteful, the defendants warned ("and here," they emphasized, "the possible inference of wastefulness was based on an allegation concerning a single provision in an employment contract”), "demand will never be required, and a derivative suit will always go forward with the board being unable to exercise judgment to refused to bring it or to terminate it, no matter what the real interests of the corporation may be."

The plaintiff feared precisely the opposite. If alleging that Fink held $47 \%$ of Meyer's stock and personally selected all of the directors was not adequate to excuse demand, demand would rarely if ever be excused. This view, according to the plaintiff, "mocks Zapata," since under such an onerous demand requirement, "the two-step procedure established by Zapata, confined as it is to demand futile cases, would rarely be invoked." ${ }^{51}$ The Supreme Court "must insure," the plaintiff concluded, "that the demand on directors issue will not 'make the derivative suit an endangered species of legal action.",52

In addition to insisting that catastrophic consequences would attend the rejection of their view, each side also sought (as the quotes in the previous two paragraphs suggest) to wrap itself in the mantle of Zapata. This was to be expected, of course. The key question left open in Zapata was when is and isn't demand excused, and it was evident to everyone that Aronson was the case that would answer this question. The outcome in this case, moreover, would significantly influence Zapata's relevance in the future. If Aronson defined demand futility narrowly (the defendant's plea), demand would rarely be excused and Zapata would wither on the vine. A broad exception to demand, by contrast, would heighten the importance of Zapata.

50 Appellants' Opening Brief, Aronson v. Lewis, No. 203 (Del S.Ct. Aug. 2, 1083), at 33. The other quotes in this paragraph are from the same page.

51 Plaintiff Below’s Brief, p.19.

52 Id. at 47. 
This is where the drama came in. In the two years since Zapata was decided, the opinion's author, Justice Quillen, had retired from the Supreme Court and returned to private practice. Justice Quillen was now a partner at Potter Anderson, the firm handling the Meyers directors' defense. Quillen had not yet made his transition when the defendants first moved to dismiss the plaintiff's complaint and did not appear in the chancery court proceedings. But his was the lead name on the defendants' Supreme Court brief, and Quillen himself presented the oral argument. Much of his argument focused on Zapata. One can only imagine what the justices were thinking when Justice Quillen said, with understandable self confidence, "Both sides in the briefing have emphasized the Zapata case," and proceeded to identify as Zapata Policy Points 1, 2 and 3 that, contrary to the chancery court opinion, a derivative plaintiff does not have "an unfettered right to bring a derivative suit" even if demand is excused; that "disinterested directors should have the opportunity to receive a demand and exercise their business judgment with regard to derivative litigation;" and that "the consequence of Zapata was to focus attention on the demand requirement." ${ }^{, 53}$ Not only had Quillen, unlike the three justices before whom he now appeared, written the Zapata opinion, but he was the only person present who had participated in the deliberations. Remarkably, neither of other two justices who decided Zapata was on the panel that would decide Aronson.

In the two years since it was decided, Zapata had proven quite unpopular ("a spectacular failure," in the words of one subsequent commentator). ${ }^{54}$ There was general agreement with the court's skepticism of special litigation committees, but the conclusion that the chancery court should exercise its own business judgment seemed to fly in the face of generations of teaching about the respective roles of courts and corporate boards: that directors not courts were the ones who made business decisions.

Justice Quillen certainly did not echo these complaints in his argument. Nor did he suggest for a moment that the Court should revisit Zapata. But his argument for a narrow exception to the demand requirement would, if the Supreme Court agreed, significantly reduce

${ }^{53}$ Aronson v. Lewis, Supreme Court Transcript, at 9-10 (Nov. 14, 1983).

${ }^{54}$ Edward B. Rock, The Logic and (Uncertain) Significance of Institutional Shareholder Activism, 79 GEO. L.J. 445 (1991)[check]. 
the future relevance of Zapata. He was asking the Court to sharply limit the reach of the case that he himself had decided.

After the author of Zapata sat down, plaintiff's attorney Joseph Rosenthal was immediately pressed to defend the Chancery Court's conclusion that demand was excused because waste could be inferred from the contract. What factual basis, Justice Moore asked, did he have for the claim that Fink was incapable of working for Meyers and thus that the contract intended to pay him for doing nothing? Fink was already 75 years old, Rosenthal said (an argument that Quillen had already parried by pointing out that many people continue to work long after they turn 70, including Delaware's governor and a majority of the U.S. Supreme Court), and that Fink also worked for Prudential. Justice Moore also worried that under the broader exception to demand advocated by the plaintiff, demand would be excused any time a derivative action was brought against a company that had a controlling shareholder.

When it issued its opinion several months later, the Delaware Supreme Court returned a decisive victory for the defendants and for a sharply constrained demand futility exception. After noting that this case addressed the "crucial issue [left] unanswered" by Zapata, the court flatly rejected the chancery court's conclusion that the court should excuse demand if it could reasonably infer from the underlying transaction that the directors had permitted a waste of the corporation’s assets. 55 "In our view," Justice Moore wrote, “demand can only be excused where facts are alleged with particularity which create a reasonable doubt that the directors' action was entitled to the protections of the business judgment rule.” As it often does with its judicial formulas, the court distilled the issue of business judgment to a two-part test: "[I]n determining demand futility the Court of Chancery ... must decide whether, under the particularized facts alleged, a reasonable doubt is created that: (1) the directors are disinterested and independent and (2) the challenged transaction was otherwise the product of a value business judgment. Hence, the Court of Chancery must make two inquiries, one into the independence and disinterestedness of the directors and the other into the substantive nature of the challenged transaction and the board's approval thereof." ${ }^{56}$ Only if the plaintiff alleges particularized facts suggesting either

55 Aronson, 473 A.2d at 807 . The quote that follows appears on p.808.

${ }^{56} I d$. at 814. 
that a majority of the board was tainted or that the transaction could not satisfy the business judgment rule will demand be excused.

There is no "there but for the grace of God" language in the court's Aronson opinion. To the contrary, Justice Moore went out of his way to reject arguments that structural bias invariably taints the decisionmaking even of ostensibly independent boards. "Critics will charge that we are ignoring the structural bias common to corporate boards throughout America," he wrote, “as well as the other unseen socialization processes cutting against independent discussion and decisionmaking in the boardroom. The difficulty with structural bias in a demand futile case is simply one of establishing it in the complaint for purposes of Rule 23.1. We are satisfied that discretionary review by the Court of Chancery of complaints alleging specific facts pointing to bias on a particular board will be sufficient for determining demand futility." 57 If Justice Moore’s opinion makes any assumption about the psychology of a corporate board, the assumption seems to be this: if a majority of the directors are independent, they are likely to constitute a critical mass that is capable (unless shown otherwise) to resist even a controlling shareholder or a powerful chief executive. ${ }^{58}$

Here, the plaintiff failed to allege sufficiently particularized facts to satisfy either prong. Because the facts in this case- most prominently, Fink's inability to perform the contract and Fink's domination of the board- were simply conclusory allegations, demand was required and the plaintiff's suit should have been dismissed for failure to make demand.

\section{Do Derivative Suits Still Matter?}

With Aronson, Delaware’s framework for determining when shareholders can pursue derivative litigation was complete. The framework and its legacy will be considered in more detail below. But we first take up a more basic issue: do derivative suits still matter?

57 Id. at 815 n.8.

58 See Leo E. Strine, Jr., The Inescapably Empirical Foundation of the Common Law of Corporations, 27 DEL. J. CORP. L. 499, 506 (2002)(drawing this conclusion). 
It is not that shareholder litigation is on its death bed, as commentators repeatedly warned throughout the twentieth century. The question, instead, is why anyone would file derivatively given the other litigation options that are now available. Since the 1960s, as the securities class action has blossomed, it has increasingly been used to police misbehavior that traditionally might have given rise to derivative litigation. Although the Supreme Court explicitly held in the 1970s that Rule 10b-5 could not be used to police fiduciary duty violations, securities litigation has achieved the same effect indirectly. The ever increasing list of items that must be disclosed, ranging from financial conditions and optional business projections under Regulation S-K, to executive compensation, requires a steady stream of information about the company's decision making. A plaintiff's attorney who believes that managers have mismanaged a company or made a questionable business decision can often frame her complaint in disclosure terms, pointing to misstatements in or omissions from the company's securities filings. Given that securities class actions avoid nearly all of the procedural obstacles that complicate a derivative suit, it is no wonder the attorneys so often invoke the securities law. "[T]he federal securities law and enforcement via securities fraud class actions today," in the words of an important recent article, "have become the most visible means of regulating corporate governance."59

So why would anyone file derivatively? One reason, not surprisingly, is that some cases cannot easily be framed either as a securities class action or as a direct action under state law. The most obvious example is alleged misbehavior by a closely held corporation. Because these corporations are not subject to the securities law disclosure requirements, disgruntled shareholders cannot frame their complaints as securities violations. Second, derivative litigation and securities class actions are often brought simultaneously, based on the same behavior, as the parties try to secure a favored venue, for instance, or simply because different lawyers are involved. Finally, in some cases, the misbehavior may be so egregious that the procedural requirements for filing derivatively do not pose a serious barrier.

In practice, derivative litigation is most prominent in cases involving close corporations, and with duty of loyalty allegations. A recent study of shareholder litigation in Delaware found, for instance, that roughly thirty percent of the derivative suits filed in 1999-2000 involved close

59 Robert B. Thompson \& Hillary A. Sale, Securities Fraud as Corporate Governance: Reflections upon Federalism, 56 VAND. L. REV. 859, 860 (2003). 
corporations, nearly all alleging duty of loyalty violations, and that roughly half of the public corporation cases also raised duty of loyalty issues. ${ }^{60}$ Many of the most prominent recent derivative cases have, as with Aronson itself, involved compensation issues.

\section{The Legacy of Aronson}

The cliche that no case is decided in isolation has rarely been more true than with the Delaware Supreme Court decision in Aronson. We have already seen how an earlier case, Zapata, made Aronson necessary and no doubt influenced the stance Aronson took. A second, equally striking influence on Aronson seems to have an emerging perception on the court that all of Delaware fiduciary duty law could be organized around a single principle, the business judgment rule. In Aronson, and in several of the court's most important takeover cases starting the following year, the court sought to define the court's doctrinal advances in terms of the business judgment rule. ${ }^{61}$ "In our view," the court wrote in Aronson, "the whole question of demand futility is inextricably bound to issues of business judgment and the standards of that doctrine's applicability." ${ }^{62}$ In Unocal, the court prefaced its analysis of duties of the directors of a takeover target with the statement that "the business judgment rule ... is applicable in the context of a takeover" and concluded that "the board acted in the exercise of sound business judgment." 63 In Moran, which legitimized the poison pill, the "primary issue," in the court's

${ }^{60}$ Robert B. Thompson \& Randall S. Thomas, The Public and Private Faces of Derivative Lawsuits, 57 VAND. L. REV. 1747 (2004). Id. at 1762 tbl 3 (25/83 lead cases nonpublic); 1766 tbl 5 (84\% of close corporation cases allege self dealing); 1772 tbl 11 (49\% of derivative suits against public companies allege self dealing)(note: table is mislabeled as “non-public”).

${ }^{61}$ Indeed, Aronson is most widely cited for its articulation of the business judgment rule, which it defines as "a presumption that in making a business decision the directors of a corporation acted on an informed basis, in good faith and in the honest belief that the action taken was in the best interests of the company.” $473 \mathrm{~A} .2 \mathrm{~d}$ at 812 .

${ }^{62} I d$.

${ }^{63}$ Unocal Corp. v. Mesa Petroleum Co, 493 A.2d 946 (Del. 1985) [Add page cites]. 
view, was "the applicability of the business judgment rule;"64 and the court said in Revlon that "the business judgment rule may be applicable to the actions of corporate directors responding to takeover threats [if] the principles upon which it is founded- care, loyalty and independence ... [are] first ... satisfied.”65

The overall project had mixed success. Perhaps the entire corpus of fiduciary duty regulation can be routed through the business judgment rule, but it is not always clear that the game is worth the candle. The business judgment rule is incidental to the real analysis in the takeover cases, which turns on the reasonableness of the target directors' response to an unwanted takeover. In Aronson, however, framing the demand inquiry in terms of the business judgment rule has proven to be a brilliant stroke. Unlike with the takeover cases, the question whether the directors would be entitled to the benefits of the business judgment rule is essential to determining whether their decision (in this case, the refusal to sue) should be respected. Viewing the demand futility through the lens of the business judgment rule thus makes perfect sense. In retrospect, Aronson demand futility standard can be seen as a side effect- a remarkably happy one, I will argue- of the court's larger quest for a unified field theory of directors' fiduciary duties in corporate law.

The first prong is where much of the action is. The classic case for excusing demand is a challenge to a transaction in which the directors each have a financial interest, as in Zapata. If all of the directors truly are implicated, nearly everyone agrees that demand should be excused. The more difficult case comes when a key manager is implicated but many of the other directors are not. Some observers believed that, because of the structural bias on boards, demand should ordinarily be excused in this case. Aronson refused to presume structural bias, as we have seen. Only if a majority of the board is either interested or can be shown to be controlled by the interested director is demand excused under Aronson's first prong.

It is worth noting that the standard for directorial disinterest in Delaware is broader and more flexible than the strict formula for disinterestedness mandated by the stock exchanges after

${ }^{64}$ Moran v. Household International, Inc., 500 A.2d 1346 (Del. 1985)[beg’g of part II].

${ }^{65}$ Revlon, Inc. V. MacAndrews \& Forbes Holdings, Inc., 506 A.2d 173 (Del. 1985) [II.A.] 
the corporate scandals. ${ }^{66}$ A so-called "gray" director- one who has ties to the company, such as working for a law firm that represents it, but is not an insider- may qualify as disinterested under Delaware's standards but will not meet the stricter stock exchange standard. A director that satisfies the stock exchange standards, on the other hand, will invariably meet the more flexible Delaware standard. Because the stock exchanges now require that a majority of the directors on every board meet their strict new standards, the first prong of Aronson is likely to recede somewhat in importance. Except with transactions that implicate all of the directors, plaintiffs will rarely be able to show that a majority of the board is interested. In these cases, demand will only be excused if they can show that a majority of the board is not independent- that is, they are controlled by the alleged wrongdoer. This showing will be much easier in cases involving closely held companies, since the shareholders of these companies generally have a close familiarity with the business and the relationships among its directors.

The second prong, which asks whether "the challenged transaction was otherwise the product of a valid exercise of business judgment," functions as a catch-all or escape valve. Even if the plaintiff cannot cast a reasonable doubt on the disinterest or independence of a majority of the directors, demand may be excused if the decision making process or the decision itself is, in a sense, inexcusable. The most prominent recent example of such as case was a derivative suit alleging that the directors of Disney violated their fiduciary duties in approving an enormous severance payment to Michael Ovitz, who had been lured to Disney by CEO Michael Eisner two years earlier. Although there was no serious question about the directors' disinterest and the plaintiff could not demonstrate their lack of independence, the decision making process was so flawed that the Delaware Supreme Court concluded that demand should be excused.

Notice the relationship between Aronson's second prong and structural bias on the board of directors. What Aronson's first prong taketh away- refusing to assume that board's are controlled by their key managers- the second prong giveth back. If board decision making is

${ }^{66}$ Under the New York Stock Exchange standard, a director is not independent if she has any "material relationship" with the company, or if she, among other things, receives more than $\$ 100,000$ per year in direct compensation from the company, is employed by a firm that is an auditor of the company, or is employed by a company that receives $\$ 1$ million or more from the company. N.Y. Stock Exchange Listed Company Manual, sec. 303A.02. 
distorted by structural bias, demand will sometimes be excused, as in Disney, even if the plaintiff can not point to particularized facts demonstrating that the outside directors lack independence.

Other than complaints by plaintiff's lawyers that the demand futility exception is now far too narrow, the principal objection to Aronson's demand standard is that it, together with Zapata, discourage plaintiff's attorneys from ever making demand on the directors. If the plaintiff makes demand and the directors conclude that the suit should be dismissed, as they always do, their decision will stand unless it is wrongful. Under an alternative favored by some commentators and adopted by the ALI, demand would be required in every case but would not give the directors any greater ability to terminate the litigation. ${ }^{67}$ While universal demand would give repentant directors an opportunity to make changes and perhaps obviate the need for litigation in some cases, it seems unlikely that this would often be the effect. More often, it would simply delay litigation.

\section{The Plaintiff's Attorney Auction}

Even if we conclude that Aronson is a masterful solution to the problem of determining which derivative suits should go forward, it is important to keep in mind that reducing the likelihood of strike suits is only one of two longstanding concerns about derivative litigation: the other is the conflict of interest between plaintiff's attorneys and their ostensible clients, the company's shareholders. Is there a way to solve this problem as well?

Over the past seventy years, commentators have floated a variety of proposals that would either displace plaintiff's attorneys or provide more oversight over their decision to sue, their handling of the case, or both. In the 1930s, several commentators proposed that the government itself should get in the shareholder litigation business, either by creating an agency to policy directorial misbehavior or by authorizing government officials such as the attorney general to sue

67 AMERICAN LAW INSTITUTE, PRINCIPLES OF CORPORATE GOVERNANCE, sec. 7.03 (requiring demand except in limited circumstances). See also Cuker v. Mikalauskas, 92 A.2d 1042 (Pa. 1997)(adopting the ALI approach for derivative suits involving Pennsylvania corporations) 
on shareholders behalf. ${ }^{68}$ More recent years have seen proposals to create a committee of shareholders or independent experts to pass judgment on the litigation. ${ }^{69}$ (The presumption in federal securities class actions that the largest shareholder will serve as the lead plaintiff is in a similar spirit.) The Achilles heel of the proposals is a suspicion that they would be cumbersome to put in place and might not improve shareholder litigation all that much.

The proposal that has gained the most traction takes precisely the opposite tack. Rather trying to create a more traditional attorney-client relationship, with the client monitoring the attorneys actions, this approach advocates that the role of plaintiff's attorney be auctioned to the law firm that offers the highest price. ${ }^{70}$ After the winning bid is distributed to shareholders or the company, the client would essentially disappear. The attorneys themselves would pursue the litigation, and would keep any recovery. Because the attorneys would be litigating on their own behalf once they paid the shareholders, their conflict of interest would disappear. They would focus on obtaining the best possible result in the case. Although no court has conducted this kind of auction to determine the lead counsel in a shareholders' suit (and practical obstacles such as prohibitions on buying stakes in litigation would interfere), courts in several securities fraud cases have asked law firms to submit applications disclosing the percentage of any recovery they expected to receive, and courts have selected lawyers based on these applications. ${ }^{71}$

While the lowest fee approach is a more realistic alternative to traditional approaches to selecting lead counsel than is a true auction, it also has more limitations. It does not fully eliminate the plaintiff's attorney's conflict of interest, for instance, since the attorney still will

${ }^{68}$ Harris Berlack, Stockholders' Suits: A Possible Substitute, 35 MICH. L. REV. 597, 609, 610 (1937). See also Roscoe Pound, Visitatorial Jurisdiction Over Corporations in Equity, 49 HARV. L. REV. 369, 393 (1936)(arguing that the Attorney General has visitatorial jurisdiction over corporations and could intervene when "mismanagement seriously affects the economic order and threatens loss to the investing public").

69 See, e.g., Rock, supra note 54 (discussing pros and cons of a shareholder committee).

${ }^{70}$ The leading analysis and defense of this approach is Jonathan R. Macey \& Geoffrey P. Miller, The Plaintiff's Attorneys Role in Class Action and Derivative Litigation: Analysis and Recommendations for Reform, 58 U. CHI. L. REV. 1 (1991).

${ }^{71}$ The best known example is In re Oracle Securities Litigation, 131 F.R.D. 688 (N.D. Cal. 1990). 
have an interest in maximizing her own fees rather than the overall recovery. The auction also could leave shareholders with incompetent counsel if poor lawyers underbid their competitors and the court did not assess the quality of the firm. If courts did take a closer look at the law firm quality, low bid auctions perhaps could help to moderate fees. Although the strategy has been used only in federal class actions to date, in principle it could be used in a derivative case as well.

\section{Aronson and the Federal Securities Law Reforms}

In the twenty-five years since Aronson, the framework for handling derivative litigation has remained relatively constant, while Congress has twice intervened to reshape the basic parameters of securities class action litigation. In 1995, Congress enacted the Private Securities Litigation Reform Act, which establishes a rebuttable presumption that the investor who has the largest stake in a securities class action will be named as the lead plaintiff in the action. The 1995 Act also requires that securities plaintiffs "state with particularity facts giving rise to a strong inference that the defendant acted with the requisite state of mind"- that is, that the defendant knowingly or recklessly violated the securities laws. ${ }^{72}$ Both of these provisions are designed to stymy strikes suits, the first by increasing the likelihood that the plaintiff will exercise meaningful oversight over the class attorneys, and the second by making it easier to kick out suits that are sloppy or obviously nonmeritorious. In 1998, Congress again intervened, forcing most plaintiffs' to bring their federal securities class action cases in federal courts after numerous plaintiffs had circumvented the strictures of the 1995 act by filing in state court.

Whether the reforms have increased the proportion of meritorious suits is still a matter of debate. The existing empirical studies are somewhat mixed, with some evidence that the reforms are achieving their intended effect and some that there has been little measurable change. ${ }^{73}$

72 Private Securities Litigation Reform Act of 1995 (PSLRA), Pub. L. No. 104-67, 109 Stat. 737 (1995), sec. 101(a) \& (b)(amending 1934 act sections 27(a) and 27D(a)).

73 The studies to date are surveyed in Stephen Choi, Do the Merits Matter Less After the Private Securities Litigation Reform Act, J.L. ECON. \& ORG. (forthcoming 2007). Choi presents 
Studies focusing on particular provisions, rather than the reforms as a whole, also do not find dramatic effects. A recent study of the lead plaintiff provision suggests that the presence of an institutional lead plaintiff slightly increases the expected settlement amount in the case, but that overall settlement amounts have not increased since the 1995 reform and the ratio of the settlement to the estimated magnitude of the company's provable losses from alleged misbehavior has actually decreased. ${ }^{74}$

Superficially, the securities class action reforms have magnified the differences between federal securities cases and state law derivative actions, since none of the new bells and whistles applies to old fashioned derivative cases. In reality, the federal changes can be seen as evidence that the two forms of shareholder litigation are evolving in the same direction. This parallel evolution is most evident with the new pleading standard, which serves, in a sense, as a substitute for Aronson's demand requirement. Like Aronson, it imposes a heightened pleading standard that is designed to discourage sloppy pleading and to ensure that only serious allegations survive. In each context, moreover, the determination whether litigation should go forward is made primarily by a court, in response to a motion to dismiss in the early stages of the case.

The real differences in securities class actions and derivative suits are found less in procedural niceties than elsewhere. As we have seen, the continuing expansion of the securities laws has created liability for behavior that would not be actionable under state law. This suggests an obvious but rarely noted conclusion about contemporary shareholder litigation. To the extent one worries about contemporary shareholder litigation, the place to look for answers is in the substantive provisions of the securities acts. Reversing the trend toward ever more expansive disclosure requirements would do far more to rein in shareholder litigation than any of the procedural changes that garner most of the attention. ${ }^{75}$

evidence that the act may have discouraged some non-nuisance claims that lacked "hard evidence" of fraud.

${ }^{74}$ James D. Cox \& Randall S. Thomas (with Dana Kiku), Does the Plaintiff Matter? An Empirical Analysis of Lead Plaintiffs in Securities Class Actions, 106 COLUM. L. REV. 1587 (2006).

${ }^{75}$ Alternatively, one could disimply investors' private right of action, as Joe Grundfest suggested some years ago. See, e.g., Joseph A. Grundfest, Disimplying Private Rights of Action 


\section{$\underline{\text { Conclusion }}$}

Shareholder litigation is probably the least loved form of litigation. In the popular perception, plaintiff's attorneys sue at the drop of a hat- or more precisely, the drop of a stock price- and they pocket huge fees in cases that provide only a token recovery for shareholders. Shareholder litigation is not the only way to police corporate directors, but it is deeply entrenched in this country. It is hard to imagine shifting to an alternative strategy, such as the use of governmental regulators one finds in the U.K.

Against this unpromising backdrop, Aronson v. Lewis has been a rather remarkable success. Its two prong test works effectively both for the close corporations that supply half of all derivative disputes, and for the high profile cases that get all of the attention. Nearly twentyfive years after Aronson, it seems fair to say that lumping derivative suits with federal securities class actions together gives derivative litigation a bad rap. All in all, at least in Delaware, the derivative mechanism works better than ever before.

Under the Federal Securities Laws: The Commission's Authority, 107 HARV. L. REV. 963 (1994)(suggesting the SEC has the power to disimply). Reversing the private right of action would leave the SEC as the principal enforcer of the provisions (like sections 10 and 14) that do not explicitly provide for a private cause of action. As difficult as this is to imagine, it may well be what the drafters of the securities acts contemplated, and it is essentially the approach one sees in the U.K. 